\title{
Church Conservatism and Services for the Elderly*
}

By: Rebecca G. Adams and Bonnie J. Stark

Adams, R.G., \& Stark, B.J. (1988). Church Conservatism and Services for the Elderly. Journal of Religion and Aging, v.4 no.3/4: 69-86.

Made available courtesy of Taylor \& Francis (Routledge):

http://www.tandf.co.uk/journals/titles/15528030.asp

***Note: Figures may be missing from this format of the document

\section{INTRODUCTION}

The local church has traditionally provided services to the elderly. ${ }^{1}$ During this century, the role of government in human services has grown and partially replaced that of local churches. ${ }^{2} \mathrm{Re}-$ cent reductions in government spending on human services, however, have led to a rediscovery of the local church by the service system. ${ }^{3}$ Research has focused mainly on the potential for linkages between churches and the social services network.

Although the pastoral care literature includes many discussions of what local churches can or should do for their older members, ${ }^{4}$ there have been very few studies of what churches have been doing for them. There are three notable exceptions. Cook $^{5}$ surveyed 111 local, regional, and national religious organizations, representing a constituency of 262,766 congregations. He identified 52 types of services provided to the elderly, 42 of which were offered at the local level. The key areas of service were fellowship, social activities, congregational and pastoral ministry, visiting, and recreational activities.

Tobin and Ellor identified 26 types of services offered to older adults by the churches in six Chicago-area communities. ${ }^{6}$ Prevalent services included some kind of assistance to participate in church services, counseling, and visitation. Using the same data, Ellor and Coates identified four basic groups of formal and information services: (1) religious programs, (2) pastoral care programs, (3) programs in which the church acted as host to social agency services, and (4) programs in which the church actually provided social services. ${ }^{7}$

Steinitz did in-depth interviews with 42 church clergymen, 40 lay leaders and elderly congregants, and 38 agency personnel and community informants in a suburb of Chicago. ${ }^{8}$ Her major findings were that most services provided by churches are organized informally, and there are few linkages between churches and social agencies. Although the authors of all three studies recognized that local churches vary tremendously in their capacity and desire to provide services to older adults. Steinitz was the only one who studied and reported this variation. She found that

\footnotetext{
* The data presented in this article were collected through the University of North Carolina at Greensboro Center for Social Research and Human Services. The first of the two surveys was conducted under contract with the Piedmont Triad Council of Governments Area Agency on Aging.
} 
the proportion of elderly members in the church, congregational size, predominant clerical style, and denominational affiliation all contributed to this variation.

Mayes ${ }^{9}$ distinguished between the primary and secondary functions of religious groups. The primary functions are spiritual or doctrinal, while the secondary functions involve social action. Congregations vary in conservatism and the tendency for churches to offer social services to older adults. Steinitz ${ }^{10}$ reported that churches that were conservative, in the secondary sense, offered fewer services to older adults than those that were not.

The relationship between church conservatism and a tendency not to offer social services to older adults is potentially particularly important in the South. Hill has observed that: "Southern religion perpetuates its tradition of minding the churches' business instead of the society's." ${ }^{11}$ If this is a pervasive situation, it may be very difficult for the aging social service network to form links with churches in the southern region. ${ }^{12}$

This article contributes to the research on the potential for linkages between local churches and the aging network in two ways. First, it reports on a study of the services offered to older adults by churches in a southern, primarily rural county. No previous study has focused on this type of population of churches. Second, it addresses the questions of whether there is a relationship between each of the two dimensions of church conservatism and the tendency to offer social services to older adults. Only the secondary or social action dimension has been studied, in this regard, before.

\section{THE DATA}

This article is based on data from a 1984-1985 mail survey of the population of churches in Davidson County, North Carolina. The survey was conducted as part of the Davidson County Study on Aging which was a comprehensive needs assessment conducted by the University of North Carolina at Greensboro Center for Social Research and Human Services (CSRHS) under contract with the Piedmont Triad Council of Governments Areas Agency on Aging. In addition to surveying the County's churches, the CSRHS collected data from its 33 community agencies, 2 acute care facilities, and 11 extended care facilities that served older adults and conducted a house-to-house survey of its elderly population.

According to the 1980 Census, Davidson County had 113,162 residents, $14 \%$ of whom were 60 years old or older. It includes two cities, Lexington and Thomasville, which had 15,711 and 14,144 residents in 1980, respectively. The remainder of the County is dotted by small towns, but is basically rural. By consulting local religious organizations and telephone books, 222 churches were identified, 21 of which appeared to have folded by the time the study was started.

The mail survey was conducted in two stages. The first questionnaire was initially mailed on November 1, 1984 and included three checklists of services. The pastors indicated which services for older adults their churches offered formally, which services their congregations provided informally, and which services the older adults in their congregations needed. The instrument also included questions about denominational affiliation, the number of members, the number of people usually attending the main service, the percentage of the congregation over the age of 60 years, and staff size. Each questionnaire was accompanied by a letter from the 
Davidson County Manager and by one from the Director of the CSRHS. Two follow-up letters and additional copies of the questionnaire were sent.

The second stage of the mail survey began on August 12, 1985, when a questionnaire was sent to each of the pastors who had returned the first one. The second questionnaire included questions about the name of the community, the ruralness of the area, the church's organizational affiliations, and the details of the formal services that the pastor had indicated were offered by his or her church. The major focus of the questionnaire, however, was on the religious beliefs and priorities of the congregation. The second stage of the survey was not part of the contracted needs assessment, so the questionnaire was only accompanied by a letter from the Director of the CSRHS. Two follow-up letters and questionnaires were sent and telephone calls were made to non-respondents to encourage them to reply.

Table 1 includes a breakdown of the response rate for each stage of the survey by denomination. Note that all religious organizations in the population were Christian. The response rate for the first stage of the survey was $55.2 \%$ (see Table 1, column 3). The response rate for.the second stage of the survey was $71.2 \%$ (see Table. 1, column 5). The overall response rate was thus $39.3 \%$ (see Table 1, column 6). The data presented in this article are on the $34.3 \%$ of the churches whose pastors answered all of the questions necessary for the analyses (see Table 1, column 8). This response rate is fairly high considering the sensitive nature of the questions included in the second questionnaire. The CSRHS received several letters from pastors who refused to answer the second questionnaire, because they suspected that we were "working for the government" and felt that the government had no business asking questions about religious beliefs.

\section{MEASURES OF FORMAL AND INFORMAL SERVICE PROVISION}

When the pastors returned the second questionnaire, it became obvious that many of the services that they had claimed to offer formally were really offered informally. Some of them had kept copies of their original answers and noticed the discrepancy. A few of them included notes such as:

I am sorry I exaggerated what our church does on the first questionnaire. We do help people get to church on a one-to-one basis, but we don't have an organized program. I wish we did. It is needed.

In other cases, the pastor did not realize that we had only asked them about formal services that they had claimed to provide a scrawled "only informal" or "one-to-one basis" across the page.

The measure of formal service provision presented here is adjusted for these discrepancies. If the pastor could not describe the formal service in the second questionnaire or the description was of an informal service, it was added to his or her list of informal services and deleted from his or her list of formal ones. About $30 \%$ of the pastors had described at least one informally provided service as a formally provided one.

\section{MEASURES OF CHURCH CONSERVATISM}

The questionnaire was designed to measure church conservatism on both the primary and secondary dimensions." The pastors indicated what proportion of their congregations (all, most, 
half, fewer than half, none) felt that: (1) if we do not preach Christ to people in other countries who have never heard about Christ, the people in these countries will be damned forever, (2) God always does what you ask God to do in prayer, and (3) the Bible is to be taken literally, word for word. They also rank ordered the importance to their congregations of: (1) prayer and public worship of the Lord, (2) Christian education, (3) evangelism, (4) supporting missions, (5) social action, (6) fostering spiritual growth in members, (7) politi-

TABLE 1

RESPONSE RATES OF CHURCHES BY DENOMINATION

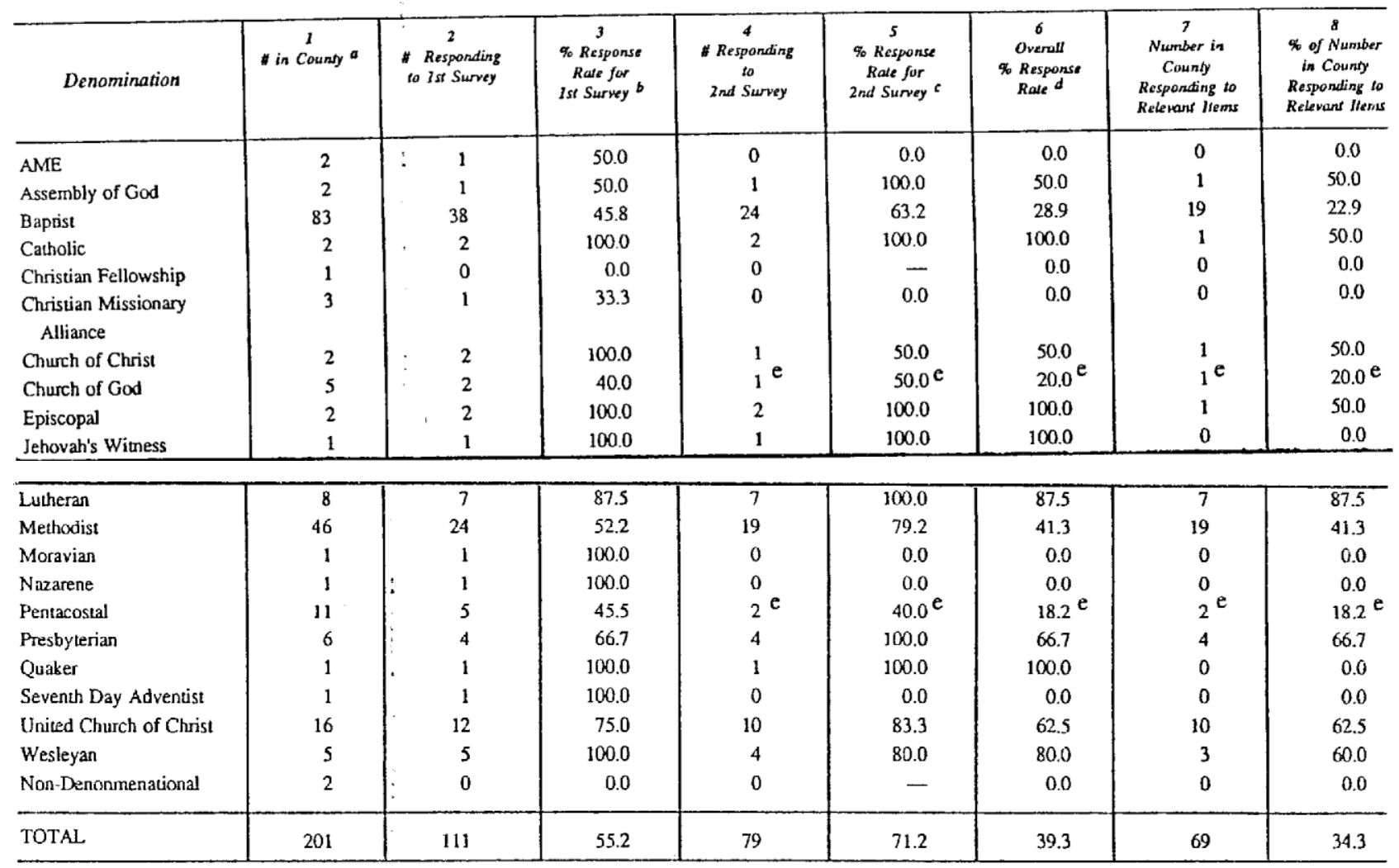

2. Twenly-one additional churches were identified and sent quessionnnaires, but they were relumed as non-fonwardable

b Column 2 divided by Colume 1

Column 4 dividad by Column 2

d Column 4 divided by Colums 1 , except sec footnote e.

e The second survey was mailed to one church of this denomination and was retumed as non-forwardabte. Response rate is based on the number deliverable.

Colunin 7 divided by Column 1, except see foolnoxe e.

cal action, (8) caring for members' non-spiritual needs, (9) community fellowship among members of the church, and (10) fellowship with other church communities.

\section{RESULTS}

\section{Two Dimensions of Church Conservatism}

The 13 items designed to measure church conservatism on doctrine and social action were submitted to a confirmatory factor analysis. Six items were eliminated because they had low correlations with other items, their measures of sampling adequacy were low, their communality with other variables was low, or they loaded highly on both factors. 
The two-factor results of the final analysis are included in Table 2. A varimax rotation and a maximum likelihood extraction were used. Bartlett's test of sphericity was significant $(\mathrm{p}<$ 0.001), and the Kaiser-Meyer-Olkin measure of sampling adequacy was acceptable (0.71). The eigenvalue for the first factor was 2.01, and the one for the second factor was 1.95. The twofactor model explained $50 \%$ of the variance and fit the data (chi-square $=10.4$, df $=13, p>$ 0.66). The variables that loaded relatively highly on each of the independent (i.e. unrelated) factors are underlined. A relatively high loading indicates that a variable was important in defining a factor.

TABLE 2

FACTOR LOADINGS FOR BELIEF VARIABLES $(N=69)$

\begin{tabular}{l|c|c}
\hline \multirow{2}{*}{ Belief Variable } & \multicolumn{2}{|c}{ Factors } \\
\cline { 2 - 3 } & Fumdlamentalism & Lack of Social Orientation \\
\hline $\begin{array}{l}\text { Those uninformed of Christ will } \\
\text { be damned }\end{array}$ & $\underline{0.32}$ & 0.05 \\
Literal interpretation of Bible & 0.32 & -0.06 \\
Evangelism a low priority & -0.60 & 0.00 \\
God always answers prayers & $\underline{0.33}$ & -0.04 \\
Political action a low priority & -0.08 & 0.72 \\
Fellowship among members \\
a low priority.
\end{tabular}

The first factor is a measure of fundamentalism. ${ }^{14}$ The congregations of churches with high scores on this dimension felt that those uninformed of Christ will be damned, interpreted the Bible literally, felt that God always answers prayers, and did not consider evangelism as a low priority. The second factor is a measure of a lack of social orientation. The congregations of churches with high scores on this dimension considered political action, fellowship among members, and the non-spiritual needs of members as high priorities.

\section{Formal and Informal Services}

Table 3 shows the percentage of churches offering each service, formally, informally, and at least one way. While only $82.6 \%$ of the churches offered at least one service formally, almost all of them did so informally $(94.2 \%)$. The six services churches most often offered formally, in order of decreasing frequency, were: outreach, a social club for older adults, emergency assistance, food distribution, transportation to church, and telephone reassurance. The six services congregation members most often offered informally, in order of decreasing frequency, were: transportation to church, outreach, telephone reassurance, transportation to important appointments, and emergency assistance. The six services most often offered at least one way, in order of decreasing frequency, were: transportation to church, outreach, telephone reassurance, emergency assistance, transportation to important appointments, and information about services.

A few generalizations can be made based on Table 3. First, as Steinitz observed, most of the services offered by the churches were 
TABLE 3

PERCENT OF CHURCES OFFERING SERVICES FORMALLY, INFORMALLY, AND FORMALLY ANDIOR INFORMALLY $(N=69)$

\begin{tabular}{|c|c|c|c|}
\hline Type of Service ${ }^{a}$ & Formally & Informally & $\begin{array}{c}\text { Formally and/or } \\
\text { Informally }\end{array}$ \\
\hline 1. Trans. to church & 24.6 & 76.8 & 82.6 \\
\hline $\begin{array}{l}\text { 2. Trans. to important } \\
\text { appointments }\end{array}$ & 2.9 & 53.6 & 53.6 \\
\hline 3. Home health care & 1.4 & 7.2 & 8.6 \\
\hline 4. Hospice & 10.1 & $\varlimsup^{b}$ & 10.1 \\
\hline 5. Counseling & 13.0 & $\omega^{b}$ & 13.0 \\
\hline 6. Outreach & 49.3 & 71.0 & 81.1 \\
\hline 7. Tel. reassurance & 20.3 & 65.2 & 68.1 \\
\hline 8. Senior recreation & 13.0 & $\ldots b$ & 13.0 \\
\hline $\begin{array}{l}\text { 9. Social club for } \\
\text { older adults }\end{array}$ & 31.9 & $\omega^{b}$ & 31.9 \\
\hline $\begin{array}{l}\text { 10. Purchasing/preparing } \\
\text { food }\end{array}$ & 2.9 & 17.4 & 18.8 \\
\hline 11. Meal delivery & 7.2 & $\omega^{b}$ & 7.2 \\
\hline 12. Food distribuiton & 27.5 & $\ldots$ & 27.5 \\
\hline 13. Light housework & 2.9 & 14.5 & 14.5 \\
\hline 14. Heavy housework & 1.4 & 18.8 & 18.8 \\
\hline 15. Reading/letter writing & 0.0 & 10.1 & 10.1 \\
\hline 16. Employment referral & 1.4 & 7.2 & 7.2 \\
\hline 17. Emergency assistance & 29.0 & 49.3 & 59.4 \\
\hline 18. Housing assistance & 1.4 & 8.7 & 8.7 \\
\hline $\begin{array}{l}\text { 19. Information about } \\
\text { services }\end{array}$ & 14.5 & 46.4 & 49.3 \\
\hline At least one & 82.6 & 94.2 & 95.7 \\
\hline
\end{tabular}

a The respondents were also asked about heaith and nutrition education, adult day care, and congregate meals, but none of the churches offered any of these services, formally or informally. An "other" category was provided, but no respondents made legtimate use of it.

b This service is by definition a formal one.

organized informally. ${ }^{15}$ Second, while the churches often provided services that probably contributed to their primary function (e.g., transportation to church, outreach, and telephone reassurance), they also performed services that one might expect from social service professionals (e.g., transportation to important appointments, emergency assistance, and information about services). Third, services that require special training or access to special resources were rarely offered by churches (e.g., home health care, hospice, counseling, employment referral, meal delivery, and housing assistance). 


\section{THE RELATIONSHIP BET WEEN CHURCH CONSERVATISM AND SERVICES OFFERED}

Table 4 reports the betas resulting from 106 two-stage regressions. A beta measures the strength of the relationship between variables. Since the scores are standardized, they can be directly compared to one another. For each regression the dependent variable was a measure of whether a church offered a service formally, whether a church offered a service informally, whether a church offered a service at least one way, the total number of formal services offered, or the total number of services offered at least one way. The following variables were entered on the first stage of each regression: number of members, number of persons usually attending the main church service, number of full-time staff equivalents, ruralness of location, and percentage of the congregation over 60 years old. On the second stage of each regression either the factor scores on fundamentalism or the factor scores on lack of social orientation were entered. The betas in the table thus represent the effect of each dimension of church conservatism on each measure of service provision, controlled for the churches' structural characteristics. A negative beta means that the more conservative a church was, the less likely they were to offer the service.

Several generalizations can be made about the results presented in Table 4. First, 27 of the 29 significant betas were positive. In other words, in general, the more conservative the churches were, the less likely they were to offer services to older adults. Second, the fundamentalism dimension was related to the lack of provision of only three services, specifically: hospice, meal delivery, and heavy housework. Third, as one would expect based on Steinitz's work, the total number of services, the total number of informal services, the total number of formal services, and the provision of many specific services were negatively affected by a lack of social orientation. $^{16}$

\section{CONCLUSIONS AND DISCUSSIONS}

The data presented here bear on three questions that are related to the general issue of whether linkages between local churches and the social service network are feasible and would make it possible to meet the needs of older adults better. The three questions are: (1) Are the social services offered to older adults by southern rural churches similar to those offered to them by northern urban churches? (2) Has southern religion continued to mind "the churches' business instead of society's"? and (3) Are conservative churches less likely than liberal churches to try to meet the non- spiritual needs of their elderly congregants?

In general, the answer to the first question appears to be a tentative "yes." The services that were offered by the Chicago area churches studied by Steinitz and Robin and Ellor were similar to those offered by the southern, primarily rural churches included in this study. ${ }^{17}$ The minor discrepancies are probably the result of the use of different methodologies and instruments. Steinitz developed her categories of service by doing participant observation and conducting unstructured interviews. ${ }^{18}$ Tobin and Ellor also did face-to- face interviews, but the categories of

their typology of services were different than those used by Steinitz. ${ }^{19}$ The Davidson County data were collected through the mail, and, once again, different service categories were used. As Streib has observed, the first step that needs to be taken is the collection of comparable observations. ${ }^{20}$ Until this has been done, it will be difficult to compare the results of different studies. 
Hill's observations that "southern religion perpetuates its tradition of minding the churches' business instead of society's" 21 appears to be an over-generalization. While it might be true that southern churches are less likely than northern churches to get in-

TABLE 4

BETAS FROM REGRESSIONS OF FUNDAMENTALISM AND LACK OF SOCIAL ORIENTATION FACTORS ON EACH SERVICE TYPE, CONTROLLING FOR \# MEMBERS, AVERAGE \# ATTENDING MAIN SERVICE, \# FULL TIME STAFF EQUIVALENTS, RURAL LOCATION, AND \% CONGREGATION 60+

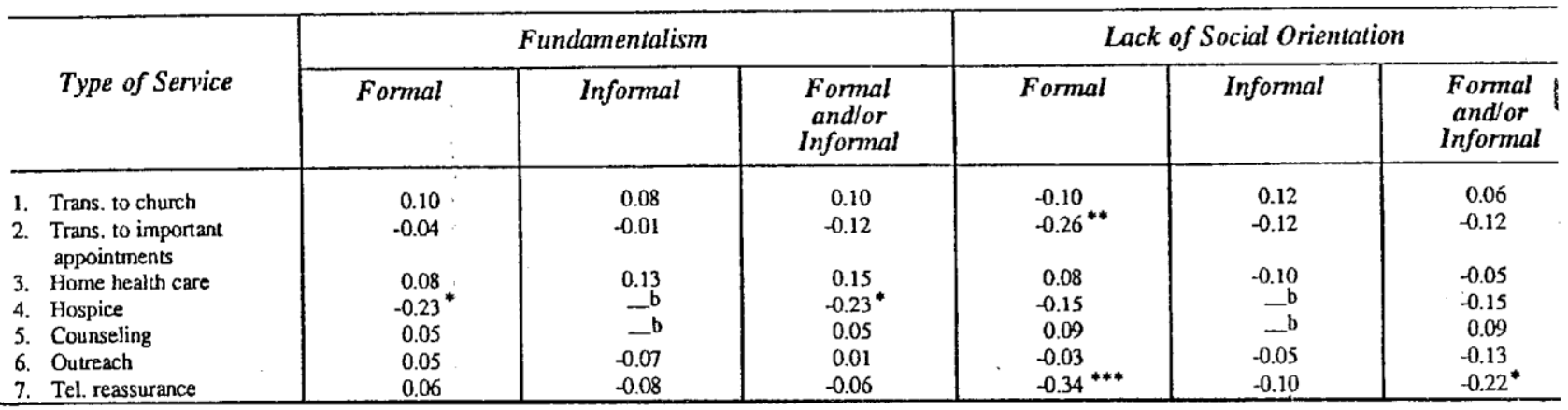

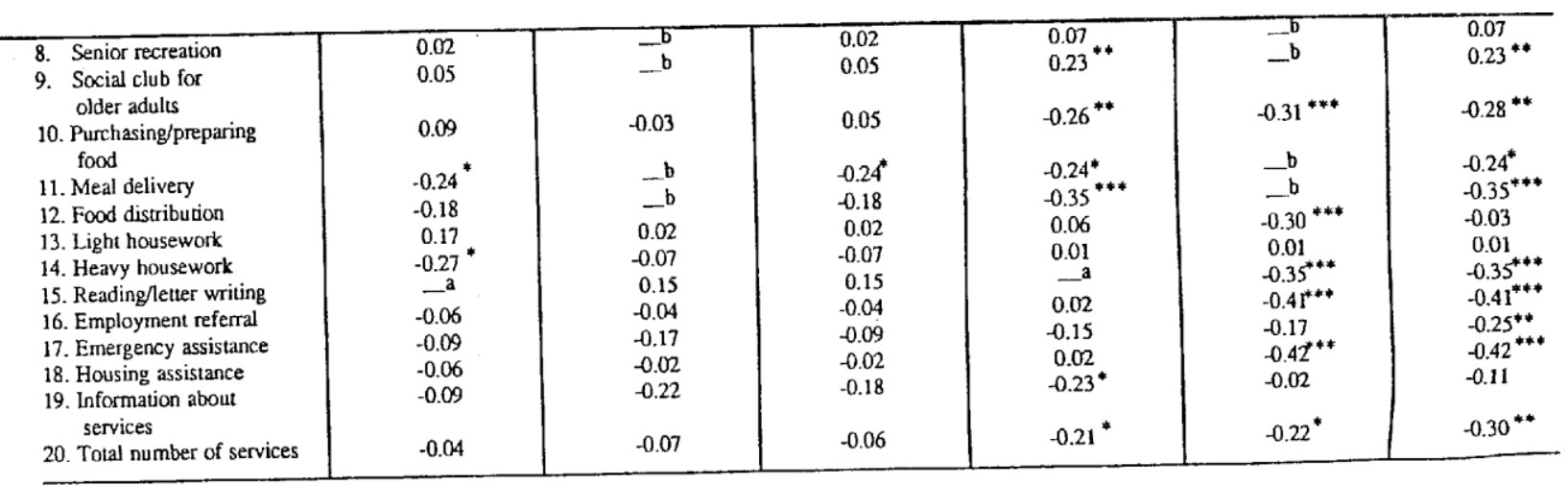

* Significant at the 0.10 level.

** Significant at the 0.05 level.

*** Significant at the 0.01 level.

a No churches offered this service.

$\mathrm{b}$ This service was assumed to be formal only.

volved in non-spiritual matters, there was great diversity in this regard among the churches included in this study. Especially in the South, the two dimensions of church conservatism, doctrinal and social, are often confused. The findings presented here corroborate Steinitz's findings that churches with conservative social orientations provided fewer services to older adults. $^{22}$ Doctrinal conservatism, in this case, fundamentalism, was not, however, an important predictor of failure to provide most types of services to the elderly.

Linkages between local churches and the social service network in areas similar to Davidson County could possibly facilitate improved service to older adults. The churches in this study offered a wide range of services to their elderly congregants, including many to meet their nonspiritual needs. The data, however, suggest that churches need access to trained personnel and 
special resources in order to offer certain types of services. These could be provided through partnership with social services agencies. It is not clear, however, if working through churches would be cost efficient or more effective.

Designers of such a collaborative project would have to proceed with care. Churches with liberal social orientations would have to be identified as potential participants. Not all churches would consider such a project appropriate. Another area of concern would be how the introduction of such a program would alter the informal service support systems already functioning in the context of churches. This issue must be carefully explored before formal linkages are considered.

\section{NOTES}

1. Paul B. Mayes, "Aging, Religion, and the Church," in Handbook of Social Gerontology, ed. Clark Tibbits (Chicago: University of Chicago Press, 1960), pp. 698-749.

2. James W. Ellor, S.M. Kanerson-Ray, and Sheldon Tobin, "The Role of the Church in Services for the Elderly," Interdisciplinary Topics in Gerontology 17(1983): pp. 119-131.

3. Gordon Streib, "Old Age, Religion, and the Solid South: Observations by a Sociologist," Southern Gerontologist 4(1984): 1,5. Sheldon S. Tobin and James W. Ellor, "The Church and the Aging Network: More Interaction Needed," Generations Fall (1983): pp. 26-28.

4. James W. Ailor, "The Church Provides for the Elderly," in Foundations in Practical Gerontology, eds. Rosamond R. Boyd and Charles G. Oakes (Columbia, S.C.: University of South Carolina Press, 1969), pp. 191-206. R. Gray and David Moberg, The Church and the Older Person (William E. Erdman Publishing Co., 1962).

5. Thomas C. Cook, The Religious Sector Explores its Mission in Aging (National interfaith Coalition on Aging, Inc., 1976).

6. Tobin and Ellor, "Church and Aging Network," pp. 26-28.

7. James W. Ellor and Robert B. Coates, "Examining the Role of the Church in the Aging Network," Journal of Religion \& Aging (forthcoming).

8. Lucy Y. Steinitz, "The Local Church as Support for the Elderly," Journal of Gerontological Social Work 4(1981): pp. 43-53; idem, "The Church within the Network of Social Services to the Elderly: Case Study of Laketown" (Ph.D. dins., University of Chicago, 1980).

9. Mayes, "Aging, Religion and Church," pp. 698-749.

10. Steinitz, "Church within Network," pp. 101-105.

11. Samuel S. Hill, The South and the North in American Religion (Athens: The University of Georgia Press, 1980), pp. 140-41.

12. Streib, "Old Age, Religion, and South," p. 1.

13. Maves, "Aging, Religion, and Church," pp. 698-749.

14. Charles Hudson, "The Structure of a Fundamentalist Christian Belief System," in Religion and the Solid South, eds. Samuel S. Hill, Edgar T. Thompson, Anne Firor Scott, Charles Hudson, and Edwin S. Gaustad (Nashville: Abingdon Press, 1972), pp. 122-142.

15. Steinitz, "Church within Network," p. 170.

16. Ibid.

17. Steinitz, "Church within Network," pp. 40-82. Tobin and Ellor, "Church and Aging Network," pp. 25-28.

18. Steinitz, "Church within Network," pp. 16-39.

19. Tobin and Ellor, "Church and Aging Network," p. 5.

20. Streib, "Old Age, Religion, and South," p. 5. 
21. Hill, South and North in Religion, pp. 140-141.

22. Steinitz, "Church within Network," pp. 101-105. 